\title{
A new raw material in the production of biodiesel: purple pinion seeds.
}

\author{
Uma nova matéria-prima na produção de biodiesel: sementes do pinhão-roxo.
}

\author{
Aluísio Marques da Fonsecal; Margareta do Carmo"; Regilany Paulo Colares'"l; \\ Camila Peixoto do Valle ${ }^{\mathrm{IV}}$; Sara Jane de Oliveirav; Juan Carlos Alvarado Alcócervi; \\ Olienaide Ribeiro de Oliveira Pinto ${ }^{\mathrm{VII}}$; José Cleiton Sousa dos Santos ${ }^{\mathrm{VIII}}$; \\ Emerson Yvay Almeida de SousalX; Francisco Felipe Maia da Silva ${ }^{\mathrm{X}}$
}

\section{Abstract}

Biodiesel is an alternative fuel that is produced through oil plants or animal fat. It is a renewable energy source, with biodegradable characteristics, to emit less pollutant than diesel. Thus, this work aims to show the production of biodiesel from the purple-pinion (Jatropha gossypiifolia L.) seeds. In addition to the synthesis, the physical-chemical characterization of both the raw material and the final product was carried out. The biodiesel synthetic route was performed by the basic catalytic transesterification reaction, using potassium hydroxide (KOH) in the presence of methanol $\left(\mathrm{CH}_{3} \mathrm{OH}\right)$ in the molar ratio of 1: 3 (oil: methanol). As a result, it was observed that the mass conversion of the biodiesel was $22.05 \mathrm{~g}$. The physical-chemical analyzes carried out were acid index of $0.106 \mathrm{mgKOH} / \mathrm{g}$, according to ANP technical resolution. The peroxide index of 1.03 meqO $/ \mathrm{kg}$, the kinematic viscosity of $20^{\circ} \mathrm{C}$ to $40{ }^{\circ} \mathrm{C}$, obtained was $6.455 \mathrm{~mm}^{2} / \mathrm{s}$ and $3.5343 \mathrm{~mm}^{2} / \mathrm{s}$, the values are close to the ANP technique resolutions. Stability was 0.26 hours, and the biodiesel burning test was executed for approximately 3 hours. Therefore, there is a high viability of biodiesel production through the purple pinion seeds.

Keywords: Renewable energy; Transesterification; Jatropha gossypifolia L.; Physical-chemical characterization.

\section{Resumo}

O biodiesel é uma alternativa de combustível que é produzido através das plantas oleaginosas ou gordura animal. É fonte de energia renovável, com características biodegradáveis, por emitir menos poluentes que o diesel. Assim, este trabalho tem como objetivo mostrar a produção de biodiesel a partir das sementes pinhão-roxo (Jatropha gossypiifolia L.). Além da síntese, foi realizado a caracterização físico-química, tanto da matéria prima, como o produto final. A rota sintética do biodiesel foi realizada pela reação de transesterificação via catalise básica, utilizando o hidróxido de potássio $(\mathrm{KOH})$ na presença de metanol $\left(\mathrm{CH}_{3} \mathrm{OH}\right)$ na razão molar de 1:3 (óleo: metanol). Como resultado, observou-se que a conversão em massa do biodiesel foi 22,05 g. As análises físico-químicas realizadas foram: índice acidez de $0,106 \mathrm{mgKOH} / \mathrm{g}$, estão de acordo com resolução técnica da ANP. O índice peróxido de 1,03 meqO $/ 2 \mathrm{Kg}$, a viscosidade cinemática de $20^{\circ} \mathrm{C}$ a $40^{\circ} \mathrm{C}$, obtida foi de $6,455 \mathrm{~mm}^{2} / \mathrm{s}$ e $3,5343 \mathrm{~mm}^{2} / \mathrm{s}$, os valores estão próximos das resoluções de técnica da ANP, a estabilidade oxidativa foi 0,26 horas, e o teste de queima do biodiesel durou aproximadamente 3 horas. Portanto, existe uma alta viabilidade de produção do biodiesel através das sementes de pião roxo.

Palavras-chave: Energia renovável. Transesterificação. Jatropha gossypifolia L. Caracterização físico-química. 


\section{Introduction}

The search for alternative fuels has been gaining prominence in recent decades. The fossil fuels substitution is motivated by environmental, economic and social factors, since the whole society depends on its use. In this sense, one option highlighted is to use biofuels (OLIVEIRA et al., 2008).

The biofuels utilization becomes a viable solution for the fuel demands to replace fossil fuels. Among the most interesting alternatives are the sources of biomass considered adequate and available for the consolidation of renewable energy programs. The use of plant biomass can be a solution to reduce the costs of fuels, such as electric power generation, turning them more accessible to isolated populations that depend on non-renewable energy sources (SILVA FILHO, 2010).

Thus, the definition of biofuel could be: any useful product for the energy generation, obtained totally or partially of biomass (TOLMAS-QUIM, 2003). During thousands of years biomass was an important primary energy source for the planet. Several organic sources can be used as biomass for the development of various society sectors, among them biofuel from oleaginous plants.

Vegetable oil is one of the largest sources of biodiesel. Biodiesel is a fuel produced from vegetable oils or animal fats and an alcohol (methanol or ethanol), in the presence of an acidic or basic catalyst, a process called transesterification (FERRARI, 2005).

To manufacture biodiesel can be used oil plants such as soybean, castor bean, jatropha, purple pineapple, babassu, rape seed, canola, palm, cotton, sunflower, saffron, coconut, peanut, canola, crambe, etc.; therefore, from the use of organic material to produce biodiesel it is possible to bring innumerable benefits to the environment, in addition to social aspects, comparing to fossil fuels (KNOTHE et al., 2006). In this way, biodiesel assumes a prominent role, presenting economic, social and environmental advantages, adding value to the studied biomass as it presents as a byproduct, few pollutants and to release less $\mathrm{CO}$ and $\mathrm{CO}_{2}$, besides being recycled in the agriculture, through agriculture family.

Present work aims to show the biodiesel production from purple pinion (Jatropha gossypiifolia L.) seeds, applying the basic catalytic via transesterification methodology adopted by Knothe et al. (2006) with some adaptations.

\section{Material and Methods}

\subsection{Search Location}

The Seeds of Purple Pinion were collected in the municipality at "Redenção" at the geographical coordinates latitude (S) 4 13 ' $33^{\prime}$ ” and longitude (WGr) 38 43' 50 " northeast at "Baturité" Massif, in the "Ceará" state (IPCE, 2017).

The research was carried out in the Organic Chemistry laboratory, University of International Integration of
African-Brazilian Lusophony (UNILAB) at the Auroras Campus, and in the fuels laboratory at "Ceará" Industrial Technology Nucleus (NUTEC).

The methodology for the preparation of biodiesel had the following steps: after the collection, the seeds were dried for oil extraction. Then, the characterization was carried out by the transesterification reaction (alcohol $+\mathrm{KOH})$ and decantation (glycerol + water). At the end of the processe, esters were usedfor the acid wash were obtaining the biodissel.

The reagents and solvents used in the synthesis and characterization of the products were all analytical grade, from the DYNAMIC brand. The reagents and solvents used were: hexane P.A $\left(\mathrm{C}_{6} \mathrm{H}_{14}\right)$; Sodium Hydroxide $(\mathrm{NaOH})$; Potassium Hydroxide (KOH); Diatomite Phenolphthalein $\left(\mathrm{C}_{20} \mathrm{H}_{14} \mathrm{O}_{4}\right)$; Methanol P.A $\left(\mathrm{CH}_{3} \mathrm{OH}\right)$; Hydrochloric Acid $(\mathrm{HCl})$; Potassium Iodide (KI); Soluble Starch $\left(\mathrm{C}_{6} \mathrm{H}_{10} \mathrm{O}_{5}\right) \mathrm{n}$; Sodium Thiosulphate $\left(\mathrm{Na}_{2} \mathrm{~S}_{2} \mathrm{O}_{3}\right)$; Acetic Acid $\left(\mathrm{CH}_{3} \mathrm{CO}_{2} \mathrm{H}\right)$; Chloroform $\left(\mathrm{CHCl}_{3}\right)$; Sodium Chloride $(\mathrm{NaCl})$; Distilled water $\left(\mathrm{H}_{2} \mathrm{O}\right)$ and Anhydrous Sodium Sulfate P.A $\left(\mathrm{Na}_{2} \mathrm{SO}_{4}\right)$.

\subsection{Purple Pinion Seeds Separation Parameters}

The Purple Pinion's seeds were collected in the Redenção municipality in pasture area. The seeds were dehydrated in a greenhouse for a period of three (3) days at $75^{\circ} \mathrm{C}$.

This process was done to improve the quality of the seeds and promote the homogenization in the extraction of oil from the purple pinion. Before drying in the greenhouse, the seeds with shells were weighed. Then, the seeds were separated between the shells and the capsulated seeds. In the separations of both, the seed mass was obtained in grams (g), and soon after were crushed in a blender.

\subsection{Processes to obtain oil from the seeds of purple pinion}

The extraction was made with a cold non polar organic solvent (Hexane P.A) in a closed container, then left for a period of three days at room temperature between the range of $24{ }^{\circ} \mathrm{C}$ to $30{ }^{\circ} \mathrm{C}$. After the three days, the liquid was separated by filtration. Then, the solvent/oil mixture sent to the rotary evaporator under the reduced pressure, which after dry with anhydrous sodium sulfate, the fixed oil was obtained (crude). In this final step, crude oil passed into a refining process.

To calculate oil production rate, equation 1 was used:

Yield $(\%)=$ Extracted oil Mass $\times 100$

Seed Mass

\subsection{Refined Oil Obtainment}

Aiming the raw material's quality improving at biodiesel production, the fixed oil obtained by extraction with organic solvent was subjected to a refining process, called neutralization followed by bleaching. The methodologies were adopted by Morais et al. (2001); Days (2009); Rodrigues (2013) and Moretto and Fett (1998). 
The process for the refining oil used the following steps: The crude oil underwent a neutralization process, then filtration and bleaching, result being the refined purple pine nut oil.

\subsubsection{Neutralization}

Crude oil was neutralized according to the methodology (DAMODARAN, PARKIN; FENNEMA, 2010). To perform the neutralization, the values of the acidity index and the crude oil's mass should be known, where it was added to a predetermined amount of sodium hydroxide $(\mathrm{NaOH})$ at $20 \%$. The mixtures were stirred at $250 \mathrm{rpm}$ to $60^{\circ} \mathrm{C}$, in a period of approximately 45 minutes. After 45 minutes, the sample was subjected to the absence of temperature and kept under magnetic agitation until reaching the ambient temperature, the mixture was left at rest for 3 hours.

\subsubsection{Whitening}

To neutralized oil was added $1 \%$ of Diatomite, then heated for 30 minutes the temperature of $70^{\circ} \mathrm{C}$, under magnetic agitation. After 30 minutes, the heating was switched off and the magnetic agitation remained until the sample reached room temperature. The sample remained at rest at room temperature for 5 hours, where it was filtered in filter paper for 24 hours. After that, the refined oil was collected for the biodiesel production. This step was adapted from the methodology (MORAIS et al. 2001).

\subsection{Analysis after treatment and characteri- zations: raw material's oil and biodiesel}

The Raw Material (purple pinion oil) was characterized for the acidity index, peroxide index, oxidization stability, specific mass and kinematic viscosity. For biodiesel, the analyzed characteristics are density, kinematic viscosity of $20^{\circ} \mathrm{C}$ to $40^{\circ} \mathrm{C}$, oxidative stability, fluidity, acidity index and peroxide index.

\subsubsection{Acidity Determination}

$2 \mathrm{~g}$ of purple pinion oil was weighed in a $125 \mathrm{~mL}$ erlenmeyer flask. Added $25 \mathrm{~mL}$ of neutral ether-Alcohol (2:1). It was added two drops of Phenolphthalein and was titrated $\mathrm{NaOH} 0.1 \mathrm{M}$ until the appearance of a pinkish coloration, which should persist for 30 seconds. The same procedure was performed with biodiesel, with the methodology adapted by the INSTITUTO ADOLFO LUZT (2008) and acidity values were based on the standard EN 14104. The calculation is made by the expression in milligrams per $\mathrm{KOH}$ per gram of oil $\mathrm{mgKOH} / \mathrm{g}$, determined by Equation 2:

$$
\text { I. } A=\frac{V_{g} \times f \times M \times 5.61}{P_{A}}
$$

Where, A. I is the acidity index, Vg represents the volume spent on sodium hydroxide titration of $0.1 \mathrm{M}$, $\mathrm{F}$ is the correction factor of the $\mathrm{NaOH}$ solution $0,1 \mathrm{M}$, $\mathrm{M}$ is the molarity of the alkaline solution and PA Is the mass of the sample in grams (g).

Another possibility of determining the acidity index is the expression through the percentages of free fatty acids (FFA \%). Thus, it is important to know the average of the molar weights of free fatty acids present in the oil, that is, to know the molar weight of oleic acid. Then use the equation 3 :

$$
\text { F.F.A\% }=\frac{V_{g} \times f \times M \times 28.2}{P_{A}} .
$$

That can be summarized as in Equation 4:

$$
\text { F.F.A\% }=0.503 \times I . A
$$

\subsubsection{Peroxide Index determination}

The oil was weighed between the range of $5 \pm 0.05$ $\mathrm{g}$ of the sample in a $250 \mathrm{~mL}$ Erlenmeyer flask. It was added $30 \mathrm{~mL}$ of the acetic acid/chloroform 3:2 solution and stirred until the dissolution of the sample. Shortly thereafter, $0.5 \mathrm{~mL}$ of a saturated KI solution was added, where it left at rest under the light for approximately one minute. It was Added $30 \mathrm{~mL}$ of distilled water and was titrated with a sodium thiosulphate solution of $0,01 \mathrm{~N}$, with constant agitation. The Titration continued until the yellow coloration disappeared. It was Added $0.5 \mathrm{~mL}$ of indicator starch solution and continued titration until the disappearance of the blue color. The same process Was made for biodiesel, with the Methodology adapted from the INSTITUTO ADOLFO LUZT (2008).

The determination of the peroxide index was made by the expression milliequivalents per $100 \mathrm{~g}$ of sample (meq/100), and the calculation was determined by the equation 5:

$$
\text { P.I. }=\frac{\left(V_{1}-V_{2}\right) x N \times f \times 1000}{P_{A}}
$$

Where, P.I is the Peroxide index, $\mathrm{V}_{1}$ represents the titration expenses of sodium thiosulphate $0.01 \mathrm{~N}$ solution in the sample in $\mathrm{mL}, \mathrm{V}_{2}$ represents the blank titration expenses, $\mathrm{F}$ is a factor of sodium thiosulphate solution and $\mathrm{P}_{\mathrm{A}}$ is the number of gram (g) of the sample.

\subsubsection{Oxidization Stability; Determination of the specific mass and kinematic viscosity}

To stabilize the purple pinion oil's oxidation, and biodiesel, is utilized standard EN 12112, adopted in Brazil by the ANP. The equipment used in the tests was the Rancimat from METROHM ${ }^{\circledR}$.

The specific mass or density and viscosities of the oils of purple pinion and biodiesel were from $20^{\circ} \mathrm{C}$ to 40 ${ }^{\circ} \mathrm{C}$, the samples were based according to the standards NBR 14065 and ASTM D445. 


\subsubsection{Fluidity Determination}

The fluidity point is an important method for biodiesel in which the temperature of the liquid cannot drain freely. It happens because biodiesel varies in every second depending on the origin of the raw material. So, these properties are considered important for ambient temperature where the fuel should be stored and used.

For the determination of the fluidity point, the ASTM D-97 method was used in the apparatus CPP5Gs.

\subsection{Processes of obtaining biodiesel from purple pinion}

In the production of biodiesel, there are several methods for its synthesis. However, this work was planned to do the transesterification process via basic catalysis. Next are all the steps for the transesterification process, a methodology adapted by (KNOTHE et al., 2006).

\subsubsection{Potassium methoxide preparation}

It was weighed approximately $0.62 \mathrm{~g}$ of $\mathrm{KOH}$ and dissolved in $10.5 \mathrm{~mL}$ of $\mathrm{CH}_{3} \mathrm{OH}$, the $45^{\circ} \mathrm{C}$. The resulting solution was used in the next step.

\subsubsection{Purple pinion oil transesterification}

Added $8.52 \mathrm{~g}$ of purple pinion's refined oil, in a $\mathrm{Be}-$ cker, warmed up in a sand bath at $45^{\circ} \mathrm{C}$, for 5 Minutes. Therefore, the solution of potassium methoxide, under agitation, was left to the heated oil, reacting for $30 \mathrm{mi}-$ nutes to $45^{\circ} \mathrm{C}$ under magnetic agitation. Transferred the mixture to a separation funnel, waiting long enough for the separation of the phases (approximately 15 minutes). He Collected the upper phase, containing the biodiesel.

\subsubsection{Neutralization and the biodiesel obtained washing}

It was added $15 \mathrm{~mL}$ of $0.5 \% \mathrm{HCl}$ in the mixture, the phase separation was stirred. It was collected the aqueous solution and repeated this procedure with $15 \mathrm{~mL}$ of a saturated $\mathrm{NaCl}$ solution. Finally, after separating the $\mathrm{NaCl}$ solution, added distilled water at $45^{\circ} \mathrm{C}$, stirred, waited for the separation of the phases and collected distilled water and measured the $\mathrm{pH}$ until to neutral 7.

\subsubsection{Combustion Test}

Three beckers were numbered and to each of it was added a cotton swab moistened with methanol, refined oil of purple pinion and biodiesel. It was set fire and observed.

\subsection{Test for cholinesterase inhibition quanti- fication}

The inhibitory activity of the enzyme acetylcholinesterase $(\mathrm{AChE})$ was measured in plates of 96 wells of flat fungus using Elisa BIOTEK Reader, model ELX 800, software "Gen5 V 2.04.11", based on the methodology described by Ellman et al. (1961). In 96 wells Plates, the following solutions were used per pit: $25 \mu \mathrm{L}$ of Acetylthiocholine iodide $(15 \mathrm{mM}), 125 \mathrm{~mL}$ of $5.5^{\text {' }}$-Ditiobis-[2-nitrobenzoic] in the Tris/ $\mathrm{HCl}$ solution $(50 \mathrm{nM}, \mathrm{pH}=8$, with $0.1 \mathrm{M}$ of $\mathrm{NaCl}$ and $0.02 \mathrm{M}$ of $\mathrm{MgCl}_{2} \cdot 6 \mathrm{H}_{2} \mathrm{O} .(3 \mathrm{mM}$, DTNB or Ellman reagent), $50 \mathrm{~mL}$ of the Tris/ $\mathrm{HCl}$ solution (50 $\mathrm{nM}, \mathrm{pH}=8$, with $0.1 \%$ of bovine serum albumin (BSA)), $25 \mu \mathrm{L}$ of the Extract sample dissolved in Ethyl Acetate and diluted 10 times in the Tris/ $\mathrm{HCl}$ solution $(50 \mathrm{mM}$, $\mathrm{pH}=8$ ) To obtain a final concentration of $0.2 \mathrm{mg} \cdot \mathrm{mL}^{-1}$ (TREVISAN et al., 2003).

The absorbance was measured at $405 \mathrm{~nm}$ for $30 \mathrm{se}$ conds. Then, $25 \mu \mathrm{L}$ of the acetylcholinesterase enzyme were added $\left(0.25 \mathrm{U} \cdot \mathrm{mL}^{-1}\right)$ and the absorbance was measured per minute up to a total of 25 minutes of incubation of the enzyme. As a negative standard, all solutions were used, except for the sample.

The dilutions of the samples and of the positive patterns used in the quantitative assessments in Microplate, departed from a mother solution with a concentration of $20 \mathrm{mg} / \mathrm{mL}$ were: $200, \mu \mathrm{G} . \mathrm{mL}^{-1}, 100 \mu \mathrm{G} . \mathrm{mL}^{-1}, 50 \mu \mathrm{G}$. $\mathrm{mL}^{-1}, 25 \mu \mathrm{G} . \mathrm{mL}^{-1}, 12.5 \mu \mathrm{G} . \mathrm{mL}^{-1}, 6.25 \mu \mathrm{G} . \mathrm{mL}^{-1}, 3.12 \mu \mathrm{G}$. $\mathrm{mL}^{-1}, 1.56 \mu \mathrm{G} . \mathrm{mL}^{-1}$, and $0.78 \mu \mathrm{G} . \mathrm{mL}^{-1}$.

The values referring to the natural colorations of the extracts were excluded from the analysis. The percentage of acetylcholinesterase inhibition was calculated by comparing the reaction velocities (substrate hydrolysis) of the samples in relation to the white (considered total activity of AChE, 100\%). The pattern used as positive control is physostigmine.

All samples were analyzed in triplicate, as follows. The samples had their own coloration absorbed by the reading wave spectrum, thus, the values referring to the staining were deducted. After the data normalization, a non-linear regression curve test was performed using the GraphPad Prism v 5.01 Statistical program.

\subsection{Composition of the diesel oil obtained from the purple pinion-Mass Spectrum (MS)}

Diesel oil analysis was performed in GC/MS Shimadzu/QP2010 using a capillary column RTX-5 (30 m x 0.25 $\mathrm{mm}, 0.25 \mu \mathrm{m}$ film thickness) and the drag gas is helium. For the temperature analysis for the essential oil furnace was programmed of $40-180^{\circ} \mathrm{C}$ at a rate of $4{ }^{\circ} \mathrm{C} / \mathrm{min}$, after $180-280^{\circ} \mathrm{C}$ at a rate of $20^{\circ} \mathrm{C} / \mathrm{min}$ and maintained at 280 ${ }^{\circ} \mathrm{C}$ for $10 \mathrm{~min}$. For the fixed temperature analysis of the oil furnace was programmed of $80-280^{\circ} \mathrm{C}$ At a rate of 5 ${ }^{\circ} \mathrm{C} / \mathrm{min}$, then from $280-300{ }^{\circ} \mathrm{C}$ at a rate of $20^{\circ} \mathrm{C} / \mathrm{min}$ and kept at $300{ }^{\circ} \mathrm{C}$ for $5 \mathrm{~min}$. The Kovat retention indexes were calculated using a series of standard $\mathrm{N}$-alkane (C7-C30). The identification of the compounds was performed by comparing their mass spectra with those of the NIST08 library, retention indexes and published data (ADAMS, 2007). 


\section{Results and Discussion}

For the determination of pinion purple's seeds separation parameter, it was obtained a moist seeds mass with shells in the value of $2 \mathrm{~kg}$, while the mass reached from shelled seeds was $888.58 \mathrm{~g}$.

In Table 1, it is showed the results of the cold extraction with Hexane P. A of the purple pinion seeds. The extraction process occurred for three days and were conducted during 5 stages. It was Observed that during the extraction of the oil showed different yields.

There are several methods for the vegetable oil extractions that leads to a large percentage viability (MORRETO; FETT, 1998), However, the best-known processes are the pressing and extraction by organic solvents That are used both for the extraction biomass oils of animal origin (fats) as vegetable (oilseed plants). In the data obtained with the extraction of oils from the seeds of purple pinion, it was considered that the methodology used expressed results Satisfactory, in which a total of Mass (g) of Crude Oil of Jatropha gossypiifolia (COJG) equal to $92.28 \mathrm{~g}$ and rate $10.38 \%$, as shown in Table 1 .

Table 1 - Purple Pinion seeds cold extraction results with hexane P.A.

\begin{tabular}{lccc}
\hline Extractions & COJG Mass (g) & Rate in \% & $\begin{array}{c}\text { Time in } \\
\text { hours }\end{array}$ \\
\hline I & 30.0 & 3.37 & 72 \\
II & 20.5 & 2.30 & 72 \\
III & 17.8 & 2.00 & 72 \\
IV & 15.9 & 1.79 & 72 \\
V & 8.08 & 0.91 & 72 \\
\hline Total & 92.28 & 10.38 & \\
\hline
\end{tabular}

Source: Authors (2019)

According to the Reis e Silva researchers (2011), were carried out extraction of purple pinion seed by Soxhlet using hexane P. A as organic solvent, presenting a rate of $7.17 \%$, with the seed mass $37.77 \mathrm{~g}$ being the oil mass 2.93 g. Comparing with the results obtained with the purple pinion seeds collected in the municipality of "Redenção" in which the rate was $10.38 \%$, and crude oil mass $92.28 \mathrm{~g}$. Is possible to report that both methods, for plant oil extraction Jatropha gossypiifolia was feasible in oil extraction. However, the data obtained in this study were higher than the data achieved by Reis e Silva (2011).

Figure 1 shows the variations of crude oil masses and the rate for purple pinion. The seeds mass from unpeeled purple pinion was $888.58 \mathrm{~g}$. It was extracted with hexane solvent P.A. The extraction was done five times. According to Silva (2010), the Plants of the Family Euphorbiaceae feature maximum extraction rate ranging between $9.09 \%$ and $33 \%$. So, the extraction process with the purple pinion seeds was quite satisfactory. A variation rate and the oil mass obtained were constant.

For a good quality in biodiesel production it must have occurred the alkyl ester and glycerol separation, so that the oil extracted from the purple pinion's seeds received a treatment, which was the clarification or bleaching of the oil. Lipids are macromolecules that
Figure 1 - Crude oil mass variation in extraction steps

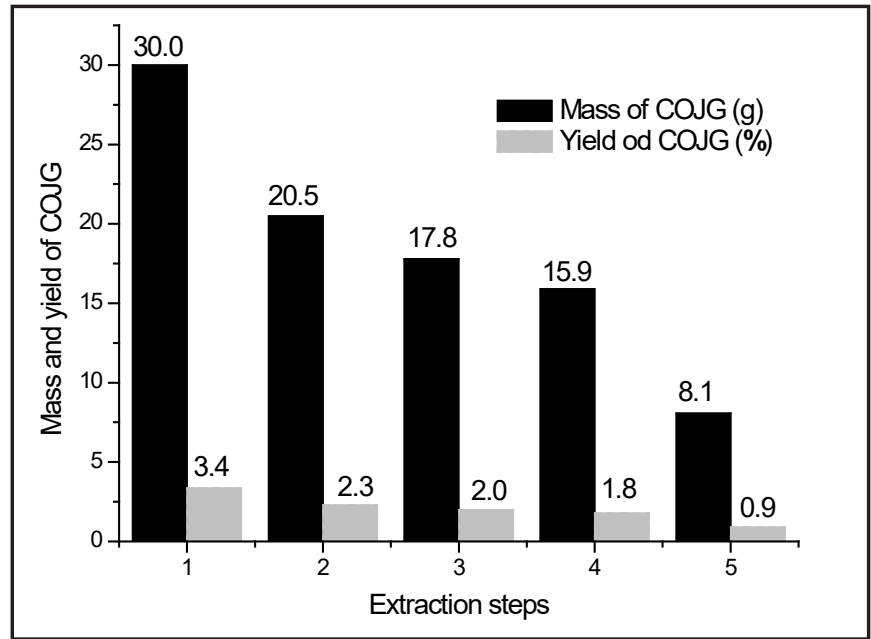

Source: Authors (2019)

present a class of chemical substances whose main characteristic is the non-polarity and solubility in organic solvents (MARTINS; LOPES; ANDRADE, 2013). So, should be withdrawn the impurities of soaps residues, traces of heavy metals, oxidization products, phosphate residues and material unsaponifiable (PAIVA, 2010), this can prevent the separation process, which is arduous, to break the long chains of triglyceride.

Therefore, this step of the refining process to remove the undesirable impurities mainly the pigments, was added an adsorbent celite diatomite type of land activated to crude oil, in which the Heating and The Filtration. celite diatomite is a type of clarifier adsorbent, the bleaching process of this work was also added the sodium hydroxide $20 \%$ in relation to the amount of acidity of the raw material, this method for the neutralization of oil. The adsorbent selectively removed the pigments that are $\triangle$ carotene (yellow and red $\mathrm{C}_{55} \mathrm{H}_{56}$ ), Xanthfila (Yellow $\mathrm{C}_{40} \mathrm{H}_{56} \mathrm{O}_{2}$ ), and chlorophyll (blue $\mathrm{C}_{55} \mathrm{H}_{72} \mathrm{O}_{5} \mathrm{~N}_{4} \mathrm{Mg}$ and Yellow $\left.\mathrm{C}_{55} \mathrm{H}_{70} \mathrm{O}_{6} \mathrm{~N}_{4} \mathrm{MG}\right)$. The comparisons between them were made in oil whitening visualization, where dark crude oil spent for yellow light oil. This was satisfactory for biodiesel production.

Refined oil of Jatropha gossypiifolia (ROJG) obtained presented mass of $46.09 \mathrm{~g}$ with a $49.95 \%$ rate in total crude oil mass. The refined were $20 \mathrm{~g}$ for the characterization of the raw material and the rest $26.09 \mathrm{~g}$ were for the process of obtaining biodiesel.

In Table 2, is presented the values of physical chemic characterization of oil pinion-purple and determination of acidity Index and peroxides index.

According to Silva (2010) oil with high acidity may compromise the motor life, because it presents a corrosive action in metal parts, which can affect the engine operation. Acidity Index determination as a chemistry parameter to determine the quality of vegetable or fat's oil can provide an important data in its preservation. Therefore, it is important to know the amount of oleic acid in general, for to set the quantity in milligrams of potassium hydroxide to neutralize a sample gram.

Comparing the values obtained with the oil's physical 
Table 2- Characterization of the seeds of purple pinion.

\begin{tabular}{lcccc}
\hline Parameter & Unity & COJG & ROJG & STANDARD \\
\hline IA & mgKOH/g oil & 4.61 & 0.47 & Adolf Luzt \\
AGL & $\%$ & 231.9 & 23.64 & - \\
IP & $\mathrm{meqO}_{2} / \mathrm{Kg}$ oil & 3.52 & 2.05 & Adolf Luzt \\
Specific Mass at $20^{\circ} \mathrm{C}$ & $\mathrm{g} / \mathrm{cm}^{3}$ & $0.9114 \pm 0.001^{*}$ & - & NBR 14065 \\
Specific Mass at $40^{\circ} \mathrm{C}$ & $\mathrm{g} / \mathrm{cm}^{3}$ & $0.8976 \pm 0.001^{*}$ & - & NBR 14065 \\
Kinematic Viscosity at $20^{\circ} \mathrm{C}$ & $\mathrm{mm}^{2} / \mathrm{s}$ & $45.312 \pm 0.01^{*}$ & - & ASTM D445 \\
Kinematic Viscosity at $40^{\circ} \mathrm{C}$ & $\mathrm{mm}^{2} / \mathrm{s}$ & $21.965 \pm 0.01^{*}$ & - & ASTM D445 \\
Oxidative Stability & hours & $3.73 \pm 0.38^{*}$ & - & EN 14112 \\
\hline
\end{tabular}

Source: Authors (2019)

chemical characterization for the purple pinion with crude oil, refined oil and biodiesel, it was found that the crude oil value obtained was $4.1 \mathrm{mg} \mathrm{KOH} / \mathrm{g}$ reducing to $0.47 \mathrm{mg}$ $\mathrm{KOH} / \mathrm{g}$ refined purple pinion oil. If raw material's acidity is high, then it is found low conversion efficiency. The excess and insufficient catalyst can cause the formations of soaps. Thus, the product obtained from biodiesel was $0.106 \mathrm{mg} \mathrm{KOH} / \mathrm{g}$ which is within the standard.

Peroxide determination is a relevant parameter for fuel production quality. According to Knothe et al. (2006), the Oxidation of an unsaturated fatty acid begins with the accumulation of peroxides. However, the oxidation of oils or fats as a high catalytic value can slow down or reduce by influence of the free radial. The consequences caused are temperature variation, enzymes, light and metal ions.

The biodiesel mass stability limit is illustrated in Table 2. The specific mass used must be in accordance with NBR 14065 Standard. However, the values obtained with the purple pinion seeds at different temperature present a variation between $20^{\circ} \mathrm{C}$ to $40{ }^{\circ} \mathrm{C}$ where was obtained $0.9114 \mathrm{~g} / \mathrm{cm}^{3}$ and $0.8976 \mathrm{~g} / \mathrm{cm}^{3}$. The Importance of this characteristic with the viscosity is that it exerts a great influence in process such as injection fuel and the preparation for automatic ignition.

The values of kinematic viscosities of the purple pinion oil in temperatures varying from $20{ }^{\circ} \mathrm{C}$ to 40 ${ }^{\circ} \mathrm{C}$ presented values between $45.312 \mathrm{~mm}^{2} / \mathrm{s}$ and 21.965 $\mathrm{mm}^{2} / \mathrm{s}$ The Ratio of the obtained values is satisfactory and feasible to produce biodiesel.

Oxidative stability is one of the analyses of great importance for the oil profile of the raw material, because appropriated values allow its use In motor consumption, as it can promote stability or durability operation of the machine. The Value obtained In oil test shows that the biodiesel product will be stable in decomposition caused by an air flow. The Induction time is determined by the conductivity measurement. The evaluation is completely automatic.

The molar ratio between alcohols (methanol): Purple pinion oil was $1: 3$ in temperature $4^{\circ} \mathrm{C}$ for 30 minutes. Reaction occurred completely and the separation of phases occurred in 15 minutes. According to Knothe et al. (2006), the process of transesterification via basic catalysis of refined vegetable oils in molar ratios of alcohol (methanol): Oil of at least 6:1 in temperature $\geq 60^{\circ} \mathrm{C}$, the reaction can be completed at 1 hour.

After obtaining Biodiesel, one drop was in the burn test. The burning time was 3 hours. Crude and refined oils do not burn during the given time. Therefore, it is possible to affirm that durability in the use of combustion motors will be viable. Besides may be exist possibility of another consumption form as its utilization at kerosene stove.

Table 3 presents the results of the characteristic analyzes of biodiesel of Jatropha gossypiifolia. L. In the determination of the acidity of the biodiesel of Jatropha gossypiifolia. L, it is observed a value $0.106 \mathrm{mgKOH} / \mathrm{g}$

Table 3 - Purple pinion biodiesel characterization

\begin{tabular}{lccc}
\hline Parameter & Unity & Value & Methodology \\
\hline IA & $\mathrm{mgKOH} / \mathrm{g}$ oil & 0.106 & Adolf Luzt \\
AGL & $\%$ & 5.33 & - \\
IP & $\mathrm{meqO}_{2} / \mathrm{g}$ oil & 1.03 & Adolf Luzt \\
Kinematic Viscosity to $20^{\circ} \mathrm{C}$ & $\mathrm{mm}^{2} / \mathrm{s}$ & 6.455 & ASTMD-2270 \\
Kinematic Viscosity to $40^{\circ} \mathrm{C}$ & $\mathrm{mm}^{2} / \mathrm{s}$ & 3.5343 & ASTMD-2270 \\
'Density to $20^{\circ} \mathrm{C}$ & $\mathrm{g} / \mathrm{cm}^{3}$ & 0.8812 & NBR14065 \\
'Oxidation Stability & hours & 0.26 & EN14112 \\
'Fluidity & ${ }^{\circ} \mathrm{C}$ & -3 & ASTMD-97 \\
\hline
\end{tabular}

Source: Authors (2019) 
being compatible and satisfactory with the technical resolution number 1/2008 of ANP that set the maximum biodiesel acid standard in $0.5 \mathrm{mgKOH} / \mathrm{g}$. The interference to the reduction of acidity posed by a treatment of the seeds of purple pinion, where the high value interferes in the transesterification reaction.

This means that most of the free fatty acids present in the oil participated in the transesterification reaction and produced the methyl esters. For these reasons, the monitoring of the acidity in biodiesel is of great importance during the storage, since it changes its values for a period, this means that the presence of the water favors the reactions of hydrolysis and proliferation of microorganism, favoring the degradation.

The biodiesel peroxide purple pinion index is 1.03 meq $\mathrm{O}_{2} / \mathrm{Kg}$ of oil, however in technical resolution number 2/2016 by ANP there's no limit value specified. This parameter is very important because it carry the degradation information about compose material in oil and in the biodiesel. According to Malacrida and Jorge (2006) the high limit doesn't must be above $10 \mathrm{meqO}_{2} / \mathrm{g}$.

The kinematic viscosity between $20{ }^{\circ} \mathrm{C}$ to $40{ }^{\circ} \mathrm{C}$ is $6.455 \mathrm{~mm}^{2} / \mathrm{s}$ and $3.5343 \mathrm{~mm}^{2} / \mathrm{s}$. The standard from ANP is $3 \mathrm{~mm}^{2} / \mathrm{s}$ for $20^{\circ} \mathrm{C}$ and $6 \mathrm{~mm}^{2} / \mathrm{s}$ at $40^{\circ} \mathrm{C}$. Its values are in agreement with the $\mathrm{N}^{\circ} 1 / 2008$ ANP resolution. The values presented in this work are inside the limits allowed by Brazilian legislation. The biodiesel kinematic must be less than viscosity for purple pinion oil. The relations for kinematic viscosity are showed in Tables 2 and 3.

Comparison between the two values of the raw material and the conversion showed a reduction in the relation between the density and the kinematic viscosity. The density of purple-pinion biodiesel was $0.8812 \mathrm{~g} / \mathrm{cm}^{3}$, compared to the limit value of technical resolution ANP No $7 / 2008$ is $850-900 \mathrm{~kg} / \mathrm{cm}^{3}$. The value obtained from the density is within the standard. This parameter is important for proper operation of the vehicle injection system, which is dependent on the raw material. Excess alcohol lowers density.

Oxidative stability determines the degradation of biodiesel. However, the value of the test for the stability of the purple pinion biodiesel was 0.26 hours; this test was based on the European standard (EN14112) by the Rancimat method. In relation to the Rancimat method, several studies show that the induction time determined results in the degradation quality of biodiesel as acidity index and kinematic viscosity. The oxidative stability of the purple-pinned methyl biodiesel was low and the induction time did not reach the limit value for ANP biofuel, this may be the greater presence of linoleic acid (C18: 2), which gives it the lowest oxidative stability (MELO, 2008).

The fluidity test is one of the specific properties of biodiesel, where it is possible to verify the ignition problem at start and performance in the fuel system of the vehicle subject to low temperatures. The tendency of the fuel is to solidify or freeze. The melt flow value was $-3^{\circ} \mathrm{C}$ for purple-pinion oil. The reduction occurs because the spatial composition of saturated fatty acids organized in the hydrocarbon chains aid in freezing. Therefore, this value possibly of the purple pinion methyl biodiesel presented the interaction of hydrogen bonds with the participation of oleic acid. In relation to ANP standards, there is no limit to these parameters until now.

After determining the esterification reaction by basic catalysis and using methanol as an acetylating agent by GC / EM, the formation was verified on a chromatogram providing a mixture of three peaks, which characterized as the main constituents of this oil. The results are shown in Figure 2.

Figure 2 - Purple pinion biodiesel chromatogram showing the characteristics formation peaks. (1) Dodecanoic acid, (2) tridecanoic acid and (3) 8-octadecinoic acid.

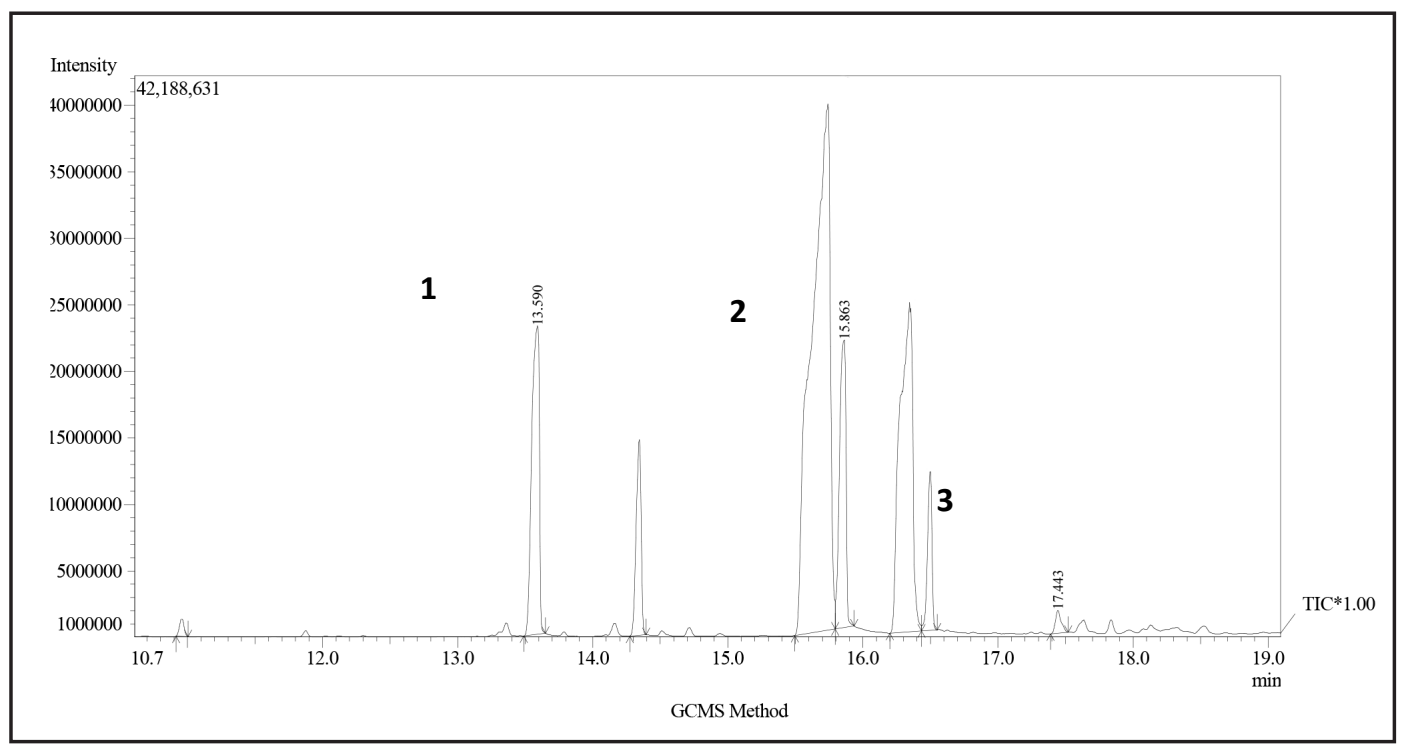

Source: Authors (2019) 
Table 4 - Purple pinion biodiesel composition by chemical route

\begin{tabular}{lcccc}
\hline Peak\# & R. Time & Name & Base m/z & Area\% \\
\hline 1 & 13.590 & Dodecanoic acid methyl ester & 74.05 & 54.01 \\
2 & 15.863 & Tridecanoic acid methyl ester & 74.05 & 42.93 \\
3 & 17.443 & 8-octadecinoic acid methyl ester & 55.05 & 3.06 \\
\hline
\end{tabular}

Source: Authors (2019)

Table 5 - Normalization curve for non linear regression by statistic sofware GraphPad Prism v5.01

\begin{tabular}{lccc}
\hline Samples & $\mathbf{I C}_{50}$ & Std. Error & $\mathbf{R}^{\mathbf{2}}$ \\
\hline Standard & 1.15 & 0.05 & 0.99 \\
Purple Pinion Ext. EtOH & 12.46 & 0.06 & 0.85 \\
\hline
\end{tabular}

Source: Authors (2019)

As shown in Table 4, the major components found in the fixed oil of purple pinion were the acids: dodecanoic, tridecanoic and 8-octadecinoic.

Table 5 shows the normalization of the non-linear regression curve. In the $\mathrm{IC}_{50}$ means values were performed the variance test with multiple comparison between pairs by the Tukey test, being considered significant values of $\mathrm{P}<0.05$.

\section{Conclusion}

The purple pinion seeds extracted with organic solvent of hexane P. A, have a $10.38 \%$ rate, being considered good. The treatment of the oil obtained features a $49.95 \%$ rate and conversion into methyl esters of $118.32 \%$.

The choice of basic catalytic transesterification allows the acidity index of the purple pinion oil crude to be 4.61 $\mathrm{mgKOH} / \mathrm{g}$, being higher than the refined oil that is 0.47 $\mathrm{mgKOH} / \mathrm{g}$ and from biodiesel, which is $0.106 \mathrm{mgKOH} / \mathrm{g}$. All these numbers are into the ANP standard given by resolution no $1 / 2008$.

The values of the characteristics between the crude oil, refined, and its conversion to methyl esters reduces, in spite of the process of treatment of the purple pinion oil in the significant form, therefore, the final production rate in oil is very necessary, since there was a significant improvement in the parameters analyzed and also facilitates the production of biodiesel.

The parameters found for biodiesel, even if not compliant with some minimum specifications of the national ANP standard but show that the biodiesel produced through the purple pinion seeds has potential for use as biofuel.

\section{Acknowledgements}

The authors thank to the Brazilian funding agencies: Cearense Foundation for Scientific and Technological Development Support (FUNCAP) project number BP30139-00005.01.00/18, National Council for Scientific and Technological Development (CNPq) project number 422942/2016-2 and Coordination of Improvement of Higher Education (CAPES) for scholarships of study and financial support.

\section{References}

ADAMS, R.P. Identification of essential oils componentes by gas chromatography/ Mass Spectrometry, Allured Publ. Corp., Carol Steam, IL, 2007.

ALMEIDA, P. M. Potencial Genotóxico do Extrato Foliar e do Látex de Pinhão-Roxo (Jatropha gossypiifolia $\mathbf{L}$.). 113 f. 2014. Tese (doutorado) - Curso de Pós-graduação em Genética, Universidade Federal de Pernambuco, Recife, 2014.

ANP - AGÊNCIA NACIONAL DE PETROLEO - Regulamento Técnico para Caracterização do Biodiesel. $\mathrm{N}^{0} 1 / 2008$. Available in: < http://legislacao. anp.gov.br/?path=legislacao-anp/resol-anp/2008/ marco\&item=ranp-7--2008>. Acess in: 12 mar. 2019.

DAMODARAN, S.; PARKIN, K.L.; FENNEMA, O.R. Química de Alimentos de Fennema. 4. ed., Porto Alegre: Artmed, 2010, 900p.

DIAS, F.P. Aproveitamento de vísceras de tilápia para produção de biodiesel. 2009. 107 f. Dissertação (Mestrado) - Curso de Pós-graduação em Engenharia Civil, Engenharia Hidráulica e Ambiental, Universidade Federal do Ceará, Fortaleza, 2009.

ELLMAN G. L., COURTNEY K. D., ANDRES V. JR., AND FEATH-ERSTONE R. M. A new and rapid colorimetric determination of acetylcholinesterase activity. Biochem. Pharmacol. V.7, p.88-95, 1961.

FERRARI, R. A.; OLIVEIRA, V. S.; SCABIO, A. Biodiesel de soja - taxa de conversão em ésteres etílicos, caracterização físico-química e consumo em gerador de energia. Química Nova, v.28, n.19, 2005.

INSTITUTO ADOLFO LUTZ. Métodos físico-químicos para análise de alimentos. São Paulo: Instituto Adolfo Lutz, 2008. 1020p. Available in: <http:www.ial.sp.gov.br/ index.html>. Acess in: 15 dez. 2008. 
IPCE. Instituto de Pesquisa e Estratégia Econômica do Ceará. Perfil básico municipal - Redenção. Fortaleza, Ceará. 2017.18p. Available in: <https://www.ipece.ce.gov. br/wpcontent/uploads/sites/45/2018/09/Redencao_2017. $\mathrm{pdf}>$.

KNOTHE, G.; KRAHL, J.; GERPEN, J. V.; RAMOS, L. P. Manual do biodiesel. São Paulo, Editora Edgard Blucher, 2006. 352 p.

KUMAR, A.; SINGH, N. Jatropha gossypiifolia L. a potential genetic resource for herbal dye. Genet Resour Crop Evol, v. 59, p. 949-954, 2012.

MALACRIDA, C.R.; JORGE, N. Influência da relação superfície/volume e do tempo de fritura sobre as alterações da mistura azeite de dendê-óleo de soja. Ciência e Agrotecnologia, v. 1, v. 30, n. 4, p.724-730, 2006.

MARTINS, C. R.; LOPES, W. A.; ANDRADE, J. B. Organic compound solubility, Quím Nova, v.36, n.8, p. 1248-1255, 2013.

MELO, W. C.; SILVA, D. B. D. et al. Produção de etanol a partir de torta de mamona (Ricinus communis $L$.) e avaliação da letalidade da torta hidrolisada para camundongos. Química Nova, v.31, p.1104-1106. 2008.

MORAIS, M. M., PINTO, L. A. D. A. et al. Estudo do processo de refino do óleo de pescado. Revista Instituto Adolfo Lutz, v.1, p. 23-33. jan. 2001.

MORETTO, E. FETT, R. Tecnologia de óleos e gorduras vegetais na indústria de alimentos. São Paulo, Editora: Livraria Varela, 1998.

OLIVEIRA, F. C. C.; SUAREZ, P. A. Z.; SANTOS, W. L. P. Biodiesel: Possibilidades e Desafios. Química Nova na Escola, p.1-6, 2008. Available in: <http://webeduc.mec.gov. br/portaldoprofessor/quimica/sbq/QNEsc28/02-QS-1707. pdf>, Acess in: 12 mar. 2019.

OLIVEIRA, J. S.; LEITE, P. M.; SOUZA, L. B.; MELLO, V. M.; SILVA, E. C.; RUBIM, J. C., MENEGHETTI, SIMONI M.P.; SUAREZ, P. A. Z. Characteristics and composition of Jatropha gossypiifolia and Jatropha curcas L. oils and application for biodiesel production. Biomass Bioenergy, v. 33, p. 449-453, 2009.

OLIVEIRA, L. L. F. Produção de biodiesel a partir do óleo das vísceras de tilapia (oreochromis niloticus) via catálise enzimática. 88 f. 2017. Dissertação (Mestrado) - Curso de Pós-graduação em Energias Renováveis, Instituto Federal de Educação, Ciência e Tecnologia do Ceará, Maracanaú, 2017.

PAIVA, E. J. M. Estudo da produção de biodiesel a partir de óleo de babaçu e etanol utilizando a transesterificação alcalina tradicional com agitação mecânica e assistida por ultrassons. 2010. 173 p. Dissertação (Mestrado em
Ciências) - Escola de Engenharia de Lorena, Universidade de São Paulo, Lorena, 2010.

RODRIGUES, J. S. Produção de Biolubrificantes a partir dos Óleos de Mamona (Ricinus communis) e de Vísceras da Tilápia do Nilo (Oreochromis niloticus). Dissertação (Mestrado em Química) - Departamento de Química. Universidade Federal do Ceará, Fortaleza, 2013.

RHEE, I.K. et al. Screening for acetylcholinesterase inhibitors from Amaryllidaceae using silica gel thinlayerchromatography in combination with bioactivity staining. Journal of Chromatography, v.915, p.217-23, 2001.

REIS, M. J.; SILVA, L. C. R. Perfil de Ácidos das Sementes da Jatropha gossypiifolia L. Revista Anais do Enic. n.3, p. 1-6, 2011. Available in: $<$ https://anaisonline.uems.br/index. php/enic/article/view/1560/1574>. Acess in: 12 mar. 2019.

SCHVARTSMAN, S. Plantas venenosas e animais peçonhentos. 2 a edição. Sarvier, São Paulo, 288p., 1992.

SILVA, S. M. L. Maryleide Ventura da. Monitoramento do processo de transesterificação do biodiesel via espectroscopia ópticas, p. 953-954, 2010.

SILVA FILHO, J. B. Produção de biodiesel etílico de óleos e gorduras residuais (ogr) em reator químico de baixo custo. 2010. 73 f. Dissertação (Mestrado) - Curso de engenharia mecânica e de materiais, Universidade Tecnológica Federal do Paraná, Manaus, 2010.

SILVA, W. C.; CASTRO, M. P. P.; PEREZ, V. H.; MACHADO, F. A.; MOTA, L.; STHEL, M. S. Thermal degradation of ethanolic biodiesel: Physicochemical and thermal properties evaluation. Energy, n.1, v. 114, p.1093-1099, 2016.

TOLMAS-QUIM, M.T. Fontes renováveis de energia no Brasil. Rio de Janeiro: Interciência, 2003. Available in: <http://www.mct.gov.br/>. Acess in: 16 fev. 2019.

TREVISAN, M.T.S.; MACEDO, F.V.V. Seleção de plantas com atividade anticolinesterase para tratamento da doença de Alzheimer. Química Nova, v.26, n.3, p.301-4, 2003. 